\title{
MENUJU GENERASI EMAS BEBAS MAKANAN SAMPAH
}

\author{
Anis Fuadah Zuhri \\ PGMI Univesitas Islam Negeri (UIN) Syarif Hidayatullah Jakarta \\ E-mail: anisfuadah.zuhri@uinjkt.ac.id
}

\begin{abstract}
Abstrak: Generasi emas merupakan generasi yang diharapkan lahir dari negeri tercinta bernama Indonesia. Generasi yang disiapkan menjadi penopang kehidupan bangsa, yang cerdas, berkarakter, dan sehat rohani jasmaninya. Generasi yang memiliki kebebasan secara fisik dan mental menikmati perkembangan kehidupan, baik dari sisi akademik. Anehnya belakangan, di antara gemerlapnya teknologi dan kemajuan sistem pendidikan yang menunjang perwujudan generasi emas Indonesia, bertaburan berbagai kasus yang mengotori usaha-usaha tersebut. Keracunan makanan hampir setiap hari, berganti tempat dari sekolah satu di daerah A, berpindah ke sekolah B di daerah lainnya. Kemudian, yang lebih memrihatinkan adalah, kejadian tersebut disebabkan oleh makanan-makanan tidak sehat, tidak memiliki nutrisi yang cukup untuk menunjang perkembangannya. Kebanyakan kasus tersebut berawal dari mengonsumsi makanan sampah, yang masih bebas dijajakan di sekitar sekolah.
\end{abstract}

Kata Kunci: generasi emas, bebas, makanan sampah

\section{PENDAHULUAN}

Hampir setiap hari, headline berita nasional maupun lokal, baik cetak atau elektronik memberitakan berbagai kejadian yang terkait keracunan makanan yang menyerang pelajar di negeri ini. Sangat memrihatinkan, karena hampir sebagian besar kejadian tersebut, diakibatkan oleh makanan di sekitar sekolah yang mereka konsumsi saat istirahat. Seperti yang digambarkan dalam kutipan puisi di bawah ini.

\section{Makanan Sampah}

(Zuhri:2015)

Mengeluhkan perutnya yang melilit, di sepertengah hari,

saat aktifitas belajar masih sangat khas beraneka tugas.

Merasakan mual, terasa pusing, dan keringat dingin.

Ada apa denganmu?

Terlihat jari-jarinya,

masih ternoda,

oleh merah sumringah, hasil zat pewarna.

Oh..

Ada yang bergegas,

meraih sebotol minyak penghangat, atau melumuri lambungnya dengan air hangat

kuku.

$\mathrm{Hmm}$.

sebuah solusi,

lima menit saja.

Tapi, taukah esok hari?

Nama dan sosok yang sama, masih membelanjakan jajanan yang serupa.

Apa pendapatmu?

Menggumam dan menggelengpun sulit, ini fakta.

Apa yang dikonsumsi, seringkali,

tak lebih dari sekadar mengunyah, melenturkan lidah, menyumpal yang tadinya kemerucuk.

Siapa yang salah? Adakah?

Betapa sulitnya,

menemukan kenikmatan yang sehat, 
dari menukar koin lima ratus rupiah.

Puisi di atas hanyalah satu kejadian, dari sekian keluhan yang menimpa anak bangsa (peserta didik), di negeri ini. Hak mereka untuk belajar dengan gembira, begitu saja terenggut beberapa saat, menyediakan waktu atas rasa sakit yang dideritanya, untuk melakukan penyembuhan, akibat makanan yang telah dikonsumsinya saat tengah istirahat. Kejadian tersebut seperti hal yang semakin membiasa terjadi di negeri ini.

Lingkungan yang nyaman bagi anak sejatinya, bukan saja pada kualitas penunjang fisik, berupa bangunan untuk menampung mereka belajar dengan baik, ataupun fasilitas lainnya yang menyebabkan pembelajaran terjadi dengan optimal. Lingkungan tersebut belum dikatakan menunjang dan menjamin kenyamanan peserta didik melaksanakan aktifitas belajar mengajar, jika lingkungan yang ramah kesehatan belum dijamin keberadaannya. Salah satu lingkungan yang ramah kesehatan tersebut adalah terjaminnya makanan yang sehat dan berkualitas bagi pertumbuhannya. Karena tak bisa dihindari, nutrisi yang baik sangat berpengaruh bagi perkembangan peserta didik, baik secara fisik maupun mental.

Sejalan dengan undang-undang Sistem Pendidikan Nasional (Sisdiknas) disebutkan bahwa, pendidikan nasional berfungsi mengembangkan kemampuan dan membentuk watak serta peradaban bangsa yang bermartabat dalam rangka mencerdaskan kehidupan bangsa, bertujuan untuk berkembangnya potensi peserta didik agar menjadi manusia yang beriman dan bertakwa kepada Tuhan Yang Maha Esa, berakhlak mulia, sehat, berilmu, cakap, kreatif, mandiri, dan menjadi warga negara yang demokratis serta bertanggungjawab. Sehat secara fisik dan mental merupakan salah satu tujuan yang tertuang dalam fungsi undang-undang Sisdiknas. Sudah seharusnya, fungsi tersebut berjalan sebagaimana mestinya, sehingga tujuan pendidikan nasional dapat terlaksana dan berhak diperoleh setiap peserta didik, di seluruh penjuru Indonesia.

Selanjutnya, mengutip Rosyada (2015), tahun 2045 Indonesia akan memasuki usia satu abad, dan pada tahun tersebut Indonesia akan memiliki jumlah usia produktif terbesar di ASEAN. Mereka yang saat ini masih sedang belajar di PAUD, pada tahun itu akan berusia 34-35, artinya orang-orang yang sedang meniti karir. Sementara mereka yang sedang kuliah saat ini, pada tahun itu akan berusia 52-54 tahun, orang yang sedang di puncak karir. Dan masih ada lagi satu generasi yang sudah lulus, serta satu generasi yang belum memasuki PAUD, yang pada tahun 2045, menjadi SDM bangsa yang menopang seluruh aspek kehidupan bangsa, politik, ekonomi, sosial dan budaya, serta pertahanan keamanan. Jika meraka itu orangorang pintar dengan karakter kebangsaan dan keIndonesiaan yang baik, maka ini akan menjadi sebuah kekuatan bangsa yang sangat dahsyat, karena lebih dari 100 juta bangsa Indonesia adalah orang-orang produktif yang akan menguasai pasar lokal dan regional, dan bahkan mungkin pasar global.

Mewujudkan cita-cita bangsa, memiliki generasi penerus bangsa yang cerdas, berkarakter, sehat, dan bermartabat memerlukan sebuah kerja keras. Menilai sisi perkembangan akademik serta kemajuan sistem pendidikan saja tidaklah cukup, karena untuk menjangkau dan mencapai tujuan tersebut, diperlukan penunjang lain yang sebetulnya adalah dasar, yaitu kesehatan fisik dan mentalnya.

\section{PEMBAHASAN}

\section{Persiapan Sejak Dini}

Lingkungan yang nyaman adalah dambaan bagi setiap individu, utamanya peserta didik, untuk melaksanakan aktifitas pembelajaran. Sarana prasana yang menunjang merupakan 


\section{1 -148 | HARKAT: Media Komunikasi Islam Tentang Gender dan Anak, 11 (2), 2015}

atribut penting sekolah, yang secara khusus disiapkan, guna memfasilitasi tiap anak didiknya. Bangunan yang aman, dekorasi kelas yang menarik, perpustakaan yang memiliki koleksi buku-buku bagus, dan teknologi canggih merupakan hal lumrah yang belakangan gencar menjadi sisi yang disebut daya tarik bagi sekolahsekolah, yang dianggap favorit. Tak mau kalah dengan tempat belajar yang berada di kota besar, sekolah-sekolah di daerah pun, kini, mulai beradaptasi dengan kemajuan tersebut. Berbagai studi banding dilaksanakan, dengan dalih, sebagai upaya meningkatkan kualitas pendidikan di lingkungan sekolahnya.

Akan tetapi, perkembangan baik tersebut seperti tengah ternoda, oleh serangkaian pemberitaan yang mulai bertebaran, baik melalui media cetak maupun elektronik. Kasus keracunan makanan seolah berpindah-pindah tempat, dari sekolah A di satu daerah, menuju sekolah lain di daerah B. Anehnya, sebagian besar kasus tersebut terjadi pada peserta didik yang membeli dan mengonsumsi makanan yang dijajakan di sekitar sekolah. Hasil uji laboratorium menyatakan (Suci:2009), kebanyakan kasus tersebut terjadi akibat makanan yang dikonsumsi mengandung formalin, rodhamin, methanol yellow, dan boraks. Bahan kimia tersebut sangat berbahaya, karena bisa menimbulkan kematian akibat rusaknya otak, hati, jantung, dan iritasi pada saluran pernapasan.

Puluhan siswa SD keracunan (Republika:2008), setelah mengonsumsi es seharga Rp. 500; per gelas plastik yang ditambah hadiah mainan, sebagai daya tarik untuk membeli. Dinas Kesehatan Banyuwangi menetapkan Kejadian Luar Biasa (KLB) (Kompas:2012), disebabkan 12 siswa SD Kemiren 1, Glagah, kabupaten Banyuwangi mengalami keracunan akibat mengonsumsi keong goreng. Puluhan siswa TK di Pekalongan keracunan (Republika:2013), setelah beberapa saat menyantap bubur ayam yang dijual pedagang keliling. Catatan minggu kesebelas dan keduabelas tahun 2015 yang disampaikan Kepala Badan Penelitian dan Pengembangan Kesehatan (Balitbangkes) Kementerian Kesehatan (Syarifah:2015), merilis enam contoh kejadian keracunan di Indonesia yang terjadi diberbagai daerah berbeda, di antaranya; keracunan pangan di kabupaten Batang - Jawa Tengah, keracunan air minum keliling di kabupaten Langkat Sumatra Utara, keracunan pangan di kabupaten Kebumen - Jawa Tengah, keracunan pangan di kabupaten Tabanan - Bali, dan keracunan pangan di kabupaten Kolaka - Sulawesi Tenggara. Puluhan siswa (Republika:2015), mengalami keracunan makanan, dan harus mendapatkan perawatan di RSUP H. Adam Malik. Sejumlah santri pondok pesantren yayasan Badahiyatul Falah, kabupaten Garut Jawa Barat (Republika:2015), mengalami keracunan setelah mengonsumsi makanan. Belajar dari kasus-kasus yang terjadi, sudah seharusnya pihak sekolah berkerjasama dengan orang tua peserta didik, serta mengerahkan masyarakat sekolah, untuk mengambil tindak lanjut agar kejadian yang banyak menimpa siswa atapun masyarakat di tempat lain, tidak terjadi di sekolahnya.

Tindak lanjut pada sekolah, juga berimbas pada kebiasan pemberian uang saku. Membahas uang saku, pun tidak serta merta begitu saja, semudah membalikkan telapak tangan. Adanya jumlah besaran uang saku, tentu memiliki keterkaitan dengan latar belakang kondisi ekonomi orang tuanya. Karena, tidak boleh begitu saja menutup mata, ternyata, beberapa kasus keracunan terjadi, oleh peserta didik yang mengonsumsi jajanan murah. Besaran uang saku di satu sekolah dengan kemampuan orang tua memberikan uang saku di sekolah dan daerah berbeda pun, memiliki besaran tak sama. Sebuah contoh, di sekolah-sekolah dan Madrasah Ibtida'iyah di kabupaten Blitar - Jawa Timur, uang saku tiga ribu rupiah tergolong besar, dan 
peserta didik sudah bisa memilih membelanjakan jajanan yang baik dan aman. Namun, kondisi tersebut akan sangat berbeda dengan para siswa yang bersekolah di kawasan Ibu Kota Jakarta, uang saku tiga ribu rupiah tentu belum cukup untuk sekadar membeli jajanan yang baik dan sehat. Besaran uang saku di satu daerah dengan di daerah lainnya, tentu tak bisa dijadika patokan, menerapkan jumlah besarannya. Kemampuan ekonomi orang tuapun, menjadi dasar membuat kebijakan.

Sejalan dengan uang saku, pilihan makanan sehat atau jajanan yang berkualitas bagi perkembangan, tak ubahnya sebuah tantangan bagi pengampu kebijakan di sekolah. Penelitian Badan Pengawas Obat dan Makanan di Jakarta menemukan kenayataan (Suci:2009) bahwa, dari 800 pedagang yang berjualan di 12 sekolah, 340 menjual jajanan yang mengandung zat kimia berbahaya. Survei lain yang dilakukan oleh POM pada tahun 2004 melibatkan ratusan sekolah dasar di Indonesia dan menampung 550 jenis makanan yang diambil dari sampel pengujian. Hasil survey tersebut menunjukkan bahwa 60\% jajanan anak sekolah tidak memenuhi standar mutu dan keamanan. Disebutkan bahwa 56\% sampel mengandung rodhamin dan 33\% mengandung boraks. Tahun 2007, POM melakukan survey kembali dengan melibatkan 4.500 sekolah di Indonesia dan membuktikan bahwa $45 \%$ jajanan anak berbahaya. Mariani dari pusat Pengembangan Kualitas Jasmani Departemen Pendidikan Nasional mengakui bahwa, selama ini masih banyak jajanan sekolah yang kurang terjamin kesehatannya dan berpotensi menyebabkan keracunan. Sudah menjadi tugas kita bersama selaku bangsa Indonesia, utamanya pihak yang terkait dengan kelangsungan pendidikan di negeri ini untuk bekerjasama, membebaskan generasi bangsa dari hiruk-pikuk makanan sampah, yang semakin hari seolah penjajah yang bergerilya meracuni lingkungan yang ramah anak.
Hal yang perlu diketahui bahwa, makanan sehat dan jajanan yang bernutrisi (Guhardja, dkk, dalam Februhartanty \& Iswarawanti, 2004, dalam Suci:2009), menyumbang 36\% energi bagi anak, $29 \%$ protein, dan $52 \%$ zat besi. Selain fasilitas fisik yang menunjang pembelajaran peserta didik, sudah selaiaknya pihak yang terkait dengan dunia pendidikan memfasilitasi pula peserta didiknya, agar mendapatkan kualitas jajanan dan makanan yang baik, di sekolah. Sebuah survey di 220 kabupaten dan kota di Indonesia (Jajanan Sekolah, 2009, dalam Suci:2009) menemukan, hanya $16 \%$ sekolah yang memenuhi syarat mengelola kantin sehat.

Kenyataannya, kebiasaan jajanan tidak sehat (Suci:2009), banyak anak sekolah yang akan mengalami hambatan dalam perkembangannya. Karena, paparan bahan kimia yang masuk ke dalam tubuh, lambat laun akan merusak, menimbulkan penyakit, bahkan kematian. Anak usia sekolah (Suci:2009) adalah, investasi bangsa yang harus dijaga dan dipelihara untuk menjadi penerus bangsa. Kualitas bangsa di masa depan sangat tergantung pada kualitas anak-anak saat ini. Pemenuhan kebutuhan tersebut, tidak berlebihan, untuk mewujudakan generasi emas Indonesia, lingkungan yang ramah jajanan dan makanan bernutrisi bagi anak menjadi salah satu hal penting yang harus diperhatikan, mulai sekarang.

Pembiasaan untuk memberikan peserta didik bekal ke sekolah merupakan salah satu solusi, agar anak terbiasa mengonsumsi makanan sehat. Sebuah penelitian menyebutkan (Sunarti:2013), ada perbedaan asupan 142ocial, asupan protein dan status gizi anak yang sekolah dengan model school feeding dan non school feeding. Penelitian tersebut juga menuliskan, bahwa, masalah kurangnya asupan (gizi), tidak hanya terkait dengan masalah kemiskinan, akan tetapi terkait pula dengan aspek 142ocial dan budaya. 


\section{3-148 | HARKAT: Media Komunikasi Islam Tentang Gender dan Anak, 11 (2), 2015}

\section{Mengambil Rujukan Negara Tetangga}

1. Canada

Canada tidak memiliki program makan siang bagi pelajar di sekolah, akan tetapi sebuah himbauan ditujukan pada para orang tua agar membekali anak mereka sebelum berangkat ke sekolah, dan pilihan lainnya mengizinkan tiap siswanya untuk pulang sementara melaksanakan makan siang di rumah.

\section{Singapura}

Singapura menyediakan kantin bagi pelajar di sekolahnya. Kantin untuk melayani pelajar dengan latar belakang berbagai suku, ras, agama, dan budaya. Umumnya, kantin di sekolahsekolah di Singapura menyediakan makanan yang lebih murah dari makanan di luar sekolah, dengan perbedaan porsi yang lebih sedikit. Tiap sekolah di Singapura, selalu menyediakan satu kantin halal. Dewan Promosi Kesehatan Singapura juga meluncurkan Program Makan Sehat di Sekolah (Healthy Eating in Schools), yang memberikan penghargaan kepada sekolah yang menyediakan makanan sehat.

\section{Finlandia}

Finlandia telah menerapkan program makanan gratis bagi pelajar di sekolah dan subsidi bagi para mahasiswa di Perguruan Tinggi. Menu yang disajikan juga harus memenuhi standar kesehatan dan gizi seimbang.

\section{Prancis}

Prancis adalah salah satu negara yang menerapkan kewajiban makan siang bagi pelajarnya. Makan siang merupakan aktifitas yang harus dinikmati oleh para pelajar, mereka harus melaksanakan makan siangnya dengan tenang dan tanpa terburu-buru. Tiap pelajar diberikan kebebasan untuk membeli makan siang di sekolah atau pulang beberapa waktu untuk menikmati makan siangnya, di rumah.

Tiap pelajar yang makan siang di sekolah hanya dikenakan biaya setengah dari harga penuh makan siangnya, separuh dari biaya tersebut telah ditanggung oleh pihak sekolah.

Pemerintah Prancis pun telah menerapkan panduan kerja rekomendasi pangan yang ditandatangani oleh Kementerian Pendidikan Nasional, bahwa makan siang sekolah harus sehat dan seimbang.

5. Malaysia

Sekolah-sekolah di Malaysia menyediakan kantin yang menjual makanan untuk para pelajar dengan harga yang lebih rendah. Pelajar yang kurang mampu memiliki kesempatan untuk mengajukan program makanan gratis, yang akan disponsori oleh asosiasi orang tua murid dan guru atau Kementerian Pendidikan.

6. India

Skema Makanan Tengah Hari (Midday Meal Scheme) di sekolah-sekolah di India adalah makan siang yang disediakan oleh lembaga pemerintah di bawah Integrated Child Development Service. Makanan yang disediakan bersifat gratis dan harus memenuhi panduan yang ditetapkan oleh kebijakan. Program yang diterapkan oleh pemerintah India merupakan program lama yang telah berlangsung sejak tahun 1925, dan merupakan program tertua untuk makanan gratis bagi pelajar sekolah di India. (Wikipedia)

Kurikulum memang menjadi landasan bagi kemajuan dan tujuan sebuah lembaga atau sekolah didirikan. Tapi, kesehatan fisik dan mental para pelajar di sekolah teramat penting untuk menjadi prioritas selain kurikulum yang telah ada. Negara-negara di luar Indonesia menjadi salah satu rujukan, bahwa pengadaan makanan siang yang telah diprogramkan merupakan hal baik untuk menjaga kualitas kesehatan fisik dan mental para pelajarnya. Begitupun Indonesia, sudah seharusnya penjagaan mutu kesehatan fisik dan mental diawali dari pola konsumsi makanan para pelajarnya. Setidaknya, penyediaan makan siang 
di sekolah menjadi salah satu solusi atas meluasnya keracunan makanan, akibat mengonsumsi jajanan atau makanan yang nutrisinya kurang baik bagi perkembangan kesehatan.

\section{Undang-Undang Persyaratan Kesehatan Makanan Jajanan}

Pemerintah dalam hal ini Kementerian Kesehatan Republik Indonesia sebenarnya telah menetapkan persyaratan kesehatan makanan jajanan. Peraturan tersebut tertuang dalam Peraturan Menteri Kesehatan Republik Indonesia Pasal 1 ayat (1) dan (2) mengenai Ketentuan Umum tentang persyaratan kesehatan makanan jajanan, yang berbunyi:

1. Makanan jajanan adalah makanan atau minuman yang diolah oleh pengrajin makanan di tempat penjualan dan atau disajikan sebagai makanan siap santap untuk dijual bagi umum selain yang disajikan jasa boga, rumah makan/restoran, atau hotel.

2. Penanganan makanan jajanan adalah kegiatan yang meliputi pengadaan, penerimaan bahan makanan, pencucian, peracikan, pembuatan, pengubahan bentuk, pewadahan, penyimpanan, pengangkutan, penyajian makanan dan atau minuman.

Peraturan Menteri Kesehatan Republik Indonesia Pasal 2 terkait Penjamah Makanan, yang berbunyi:

1. Penjamah makanan jajanan dalam melakukan kegiatan pelayanan penanganan makanan jajanan harus memenuhi persyaratan antara lain:

a. tidak menderita penyakit yang mudah menular misal batuk, pilek, influenza, diare dan penyakit perut dan sejenisnya;

b. menutup luka, (pada luka terbuka/bisul atau luka lainnya); c. menjaga kebersihan tangan, rambut, kuku, dan pakaian;

d. memakai celemek dan tutup kepala;

e. mencuci tangan stiap kali hendak menangani makanan.

2. Di samping ketentuan sebagaimana dimaksud pada ayat (1) penjamah makanan jajanan dalam memberikan pelayanannya dilarang memberikan anatara lain:

a. menjamah makanan tanpa alat/perlengkapan, atau tanpa alas tangan;

b. sambil merokok, menggaruk anggota badan (telinga, hidung, mulut, atau bagian lainnya;

c. batuk atau bersin di hadapan makanan jajanan yang disajikan dan atau tanpa menutup mulut atau hidung.

Peraturan Menteri Kesehatan Republik Indonesia Pasal 3 terkait Peralatan Makanan, yang berbunyi:

1. Peralatan yang digunakan untuk mengolah dan menyajikan makanan jajanan harus sesuai dengan peruntukannya dan memenuhi persyaratan kesehatan.

2. Untuk menjaga peralatan sebagaimana dimaksud pada ayat (1);

a. peralatan yang sudah dipakai dicuci dengan air bersih dan dengan sabun;

b. lalu dikeringkan dengan pengering/lap yang bersih;

c. kemudian peralatan yang sudah bersih tersebut disimpan di tempat yang bebas pencemaran.

3. Dilarang menggunakan kembali peralatan yang dirancang hanya untuk sekali pakai.

Peraturan Menteri Kesehatan Republik Indonesia Pasal 4 terkait Air, Bahan Makanan, Bahan Tambahan, dan Penyajian yang berbunyi: 


\section{5-148 | HARKAT: Media Komunikasi Islam Tentang Gender dan Anak, 11 (2), 2015}

1. Air yang digunakan dalam penanganan makanan jajanan harus air yang memenuhi standar dan persyaratan kesehatan yang berlaku bagi air bersih atau air minum.

2. Air bersih yang digunakan untuk memasak minuman harus dimasak sampai mendidih.

Terkait Air, Bahan Makanan, Bahan Tambahan, dan Penyajian, Pasal 5 menyatakan bahwa:

1. Semua bahan yang diolah menjadi makanan jajanan harus dalam keadaan baik mutunya, segar, dan tidak membusuk.

2. Semua bahan olahan dalam kemasan yang diolah menjadi makanan jajanan harus bahan olahan yang terdaftar di Departemen Kesehatan, tidak kadaluarsa, tidak cacat atau rusak.

Terkait Air, Bahan Makanan, Bahan Tambahan, dan Penyajian, Pasal 6 menyatakan bahwa, Penggunaan bahan tambahan makanan dan bahan penolong yang digunakan dalam mengolah makanan jajanan harus sesuai dengan perundang-undangan yang berlaku.

Terkait Air, Bahan Makanan, Bahan Tambahan, dan Penyajian, Pasal 7 menyatakan bahwa:

1. Bahan makanan, serta bahan tambahan makanan dan bahan penolong makanan jajanan siap saji harus disimpan secara terpisah.

2. Bahan makanan yang cepat rusak atau membusuk harus disimpan dalam wadah terpisah.

Terkait Air, Bahan Makanan, Bahan Tambahan, dan Penyajian, Pasal 8 menyatakan bahwa, Makanan jajanan yang disajikan harus dengan tempat/alat perlengkapan yang bersih, dan aman bagi kesehatan.
Terkait Air, Bahan Makanan, Bahan Tambahan, dan Penyajian, Pasal 9 menyatakan bahwa:

1. Makanan jajanan yang dijajakan harus dalam keadaan terbungkus dan atau tertutup.

2. Pembungkus yang digunakan dan atau tutup makanan jajanan harus dalam keadaan bersih dan tidak mencemari makanan.

3. Pembungkus sebagaimana ayat (2) dilarang ditiup.

Terkait Air, Bahan Makanan, Bahan Tambahan, dan Penyajian, Pasal 10 menyatakan bahwa:

1. Makanan jajanan yang diangkut, harus dalam keadaan tertutup atau terbungkus dan dalam keadaan bersih.

2. Makanan jajanan yang diangkut harus dalam wadah yang terpisah dengan bahan mentah sehingga terlindung dari pencemaran.

Terkait Air, Bahan Makanan, Bahan Tambahan, dan Penyajian, Pasal 11 menyatakan bahwa, Makanan jajanan yang siap disajikan dan lebih dari 6 jam apabila masih dalam keadaan baik, harus diolah kembali sebelum disajikan.

Sebenarnya, jika para pihak telah memenuhi persyaratan yang tertuang Peraturan Menteri Kesehatan Republik Indonesia Nomor 236, tentang persyaratan kesehatan makanan jajanan, kejadian keracunan di berbagai kota yang berbeda di Indonesia, dapat diminimalisir.

Para pedagang, masyarakat di sekolah, sampai Dinas Kesehatan setempat memiliki tugas yang sama, yaitu mewujudkan lingkungan sekolah dan lingkungan anak yang terbebas dari makanan yang kurang sehat.

Bila aturan tersebut telah terlaksana dengan baik, maka kesehatan fisik dan mental 
peserta didik terjaga dengan baik, aktifitas pembelajaran dapat berjalan optimal tanpa terkendala sakit yang diakibatkan oleh makanan atau jajanan yang kurang sehat, dan akan terwujud generasi yang sesuai harapan dan citacita bangsa Indonesia.

\section{Prestasi Belajar dan Kesehatan Makanan}

Prestasi akademik merupakan salah satu hasil dari proses pembelajaran yang dilaksanakan beberapa waktu. Hasil yang didapat berupa kumpulan nilai yang terakumulasi dalam tahapan waktu dan tingkatan kelas yang telah ditentukan.

Syah (2010) yang dikutip dari Lustika (2014), menyebutkan bahwa faktor internal yang memengaruhi prestasi peserta didik meliputi aspek fisiologis dan aspek psikologis. Faktor asupan zat gizi dan status gizi termasuk aspek fisiologis. Asupan zat gizi makro adalah faktor utama yang berperan dalam menyediakan energi bagi otak untuk bisa bekerja secara optimal (Mariana 2011 dalam Lustika 2014). Salah satu faktor yang berhubungan dengan prestasi belajar yang baik adalah asupan energi yang optimal (Febriani, 2013). Hasil penelitian Masdewi, dkk (2013) yang dikutip dari Lustika (2014) menyebutkan bahwa status gizi berhubungan dengan prestasi belajar siswa akselerasi SMPN 1 Malang.

Mengutip Febriani (2013) dalam Masdewi, dkk. (2011), terdapat hubungan yang signifikan antara perilaku makan dan status gizi dengan prestasi belajar. Penelitian serupa mengenai hubungan kemampuan kognitif, aktifitas fisik dan berat badan di Belanda menyatakan bahwa seseorang dengan kebiasaan makan sehat dan aktifitas fisik lebih, sering memiliki score kemampuan kognitif yang lebih tinggi (Febriani dalam Junger (2010).

Beberapa penelitian terdahulu telah mneyatakan dengan jelas, mengenai adanya hubungan yang erat antara nutrisi yang terkandung dalam makanan dan prestasi akademik yang diperoleh pelajar. Upaya bersama untuk membuat gerakan makan dan jajan sehat bagi para pelajar menjadi dasar bagi pertumbuhan kesehatan fisik dan mental, juga kesehatan untuk berfikir, dalam hal ini menuju prestasi akademik.

Menjadi tugas semua pihak; baik orang tua, warga sekolah, pemerintah setempat, dan dinas kesehatan terkait untuk saling membantu mewujudakan gerekan sehat, menuju generasi emas bebas makanan sampah. Bagi semua pihak perlu membuka kesadaran, bahwa dengan perilaku dan gerakan yang baik mengenai makanan sehat, ke depan Indonesia akan menjadi negara yang lebih baik dan produktif.

\section{Menuju Generasi Emas Bebas Makanan Sampah}

Mewujudakan generasi emas, sudah menjadi tanggung jawab bersama, sejalan dengan perwujudan undang-undang Sistem Pendidikan Nasional (Sisdiknas) yang menyebutkan bahwa, pendidikan nasional berfungsi mengembangkan kemampuan dan membentuk watak serta peradaban bangsa yang bermartabat dalam rangka mencerdaskan kehidupan bangsa, bertujuan untuk berkembangnya potensi peserta didik agar menjadi manusia yang beriman dan bertakwa kepada Tuhan Yang Maha Esa, berakhlak mulia, sehat, berilmu, cakap, kreatif, mandiri, dan menjadi warga negara yang demokratis serta bertanggungjawab.

Sehat secara fisik dan mental merupakan salah tujuan yang tertuang dalam fungsi undangundang Sisdiknas. Sudah seharusnya, fungsi tersebut berjalan sebagaimana mestinya, sehingga tujuan pendidikan nasional dapat terlaksana dan berhak diperoleh setiap peserta didik, di seluruh penjuru Indonesia.

Mengutip, Nuh (2012) dalam Rosyada (2015), hasil dari upaya mengembangkan grand dsign pendidikan, diharapkan terbentuk generasi yang cerdas komprehensif, antara lain produktif, 


\section{7-148 | HARKAT: Media Komunikasi Islam Tentang Gender dan Anak, 11 (2), 2015}

inovatif, damai interaksi sosialnya, sehat dan menyehatkan dalam interaksi alamnya, san berperadaban unggul. Bekerjasama dengan seluruh pihak yang terkait dengan pendidikan, berupaya keras mengupayakan penerapan hidup sehat, utamanya di lingkungan sekolah, menjadi tanggungjawab guna mewujudkan generasi Indonesia emas yang bahagia di lingkungan yang bebas penjajahan makanan sampah.

Untuk menjadikan wacana ini menjadi realita, maka perlu adanya lembaga yang memulai mensosialisasikan gerakan sehat bebas makanan sampah. Gerakan tersebut dimulai dari lingkungan keluarga, karena para orang tua yang memiliki putera puteri yang sedang bersekolah tentunya harus memiliki kesadaran yang tinggi untuk memfasilitasi perkembangan kesehatan fisik dan mentalnya dengan makanan yang baik dan sehat.

$\mathrm{Hal}$ tersebut juga harus selaras dengan program pemerintah yang turut serta memberikan dukungan subsidi untuk mensejahterakan warganya lewat program gerakan sehat bebas makanan sampah. Adanya kegiatan sosialisasi untuk masyarakat terkait makanan sehat dan penting bagi kesehatan tubuh dan perkembangan rohani jasmanai. Dengan adanya program tersebut diharapkan kesadaran yang tinggi dari masyarakat akan memperkuat suksesnya gerakan sehat bebas makanan sampah.

Jika masyarakat, dalam hal ini orang tua dan pemerintah telah satu tujuan bersinergi untuk mewujudkan gerakan sehat bebas makanan sampah, sudah menjadi tanggung jawab pihak sekolah untuk menjadi pemerhati peserta didik dalam mendidik dan mewujudkan program tersebut di lingkungan sekolah. Pihak sekolah perlu membuat aturan bagi para pedagang yang seringkali ramai pada waktu istirahat berada di lingkungan sekolah. Sekolah perlu menggandeng Dinas Kesehatan setempat untuk menseleksi jajanan mana atau makanan apa yang baik dikonsumsi oleh anak didiknya atau warga sekolah.

Sukses gerakan sehat bebas makanan sampah bukan hanya milik masyarakat sekolah, namun jika gerakan ini mampu terwujud, maka kesuksesan ini milik Indonesia sepenuhnya, untuk mencapai dan mewujudkan generasi umnggul, kompetitif, cemerlang, dan produktif yang sehat rohani jasmani dan memiliki daya saing tinggi. Mewujudkan Generasi Emas Bebas Makanan Sampah.

\section{PENUTUP}

Penjajah yang merenggut kebebasan hidup dan berkembang rakyat Indonesia memang telah berlalu, seiring kemerdekaan Indonesia ke-70. Namun kondisi pendidikan, ekonomi, dan social di Indonesia tak lantas berkembang secara ideal sesuai amanat Undang-undang. Anak-anak, yang menjadi generasi penerus bangsa, kini, ternyata diambang penjajahan dari bangsanya sendiri. Makanan menjadi salah satu sumber dari kenikmatan memikat sesaat yang tak ubahnya racun, bagi tubuh mereka. Penjajahan sedang berkembang di negeri ini, bukan berwujud manusia membawa senapan, membawa senjata tajam, atau membawa bahan peledak, tapi penjajahan berbentuk zat pewarna, bahan pengawet yang tidak seharusnya digunakan, dan makanan tidak laiak konsumsi.

Kebiasan baik, pembiasaan hidup sehat, sudah seharusnya sejak dini menjadi rutinitas baik yang harus diterapkan, baik di lingkungan keluarga dan sekolah. Lingkungan fisik yang menunjang pembelajaran, fasilitas berbasis teknologi modern menopang perkembangan pembelajaran peserta didik menuju generasi Indonesia yang cemerlang. Namun, yang tak kalah perhatian khusus adalah, pembebasan peserta didik dari wilayah yang menjajakan jajanan dan makanan yang tidak ramah kesehatan peserta didik. Mewujudkannya adalah 
tanggungjawab bersama. Menuju Generasi Emas Bebas Makanan Sampah.

\section{DAFTAR PUSTAKA}

Febriani, K. (2013). Hubungan Asupan Energi Jajanan Prestasi Belajar Remaja di SMP PL Demonico Savio Semarang (Artikel Penelitian, Program Studi Ilmu Gizi Fakultas Kedokteran Universitas Diponegoro Semarang).

http://www.hc-sc.gc.ca/fn-an/securit/kitchencuisine/school-lunch_repas-ecoleeng.php Health Canada: Be Food Allergy Aware When Packing School Lunches.

http://www.hpb.gov.sg/programmes/article.aspx? id=3088 (Wikipedia) TV Newscast 2008-10-09, MTV3 channel.

Lustika, FN. (2014). Hubungan Antara Aspan Karbohidrat, Protein Dan Status Gizi Dengan Prestasi Belajar Siswa Di Pondok Madrasah Aliyah Al-Manshur Popongan, Tegal Gondo, Klaten (Naskah Publikasi, Program Studi Ilmu Gizi S1 Fakultas Ilmu Kesehatan Universites Muhammadiyah Surakarta).

Makanan Sampah. (2015). Diunduh dari http://www.konfrontasi.com/content/b udaya/puisi.
Penyehatan Makanan dan Minuman Kliping Kejadian Luar Biasa Keracunan Makanan. Diunduh dari http://www.Vio Ardilles Putra B.blogspot.com. Putra, A. V. (2015).

Peraturan Menteri Kesehatan Republik Indonesia Nomor 236/MENKE S/PER/IV/1997/tentang persyaratan makanan jajanan meneteri kesehatan republik indonesia.

Rosyada, D. (2015). Pembelajaran Integratif Menuju Indonesia Emas 2045. Seminar Internasional. Jakrta: Fakultas Ilmu Tarbiyah dan Keguruan, Pendidikan Guru Madrasah Ibtida'iyah.

Suci, E. S. T. (2009). Gambaran Perilaku Jajanan Murid Sekolah Dasar di Jakarta. Psikobuana, Vol. 9, No. 1, 2938.

Sunarti. (2013). Perbedaan Asupan Energi, Protein dan Status Gizi Anak Usia Pra Sekolah di Sekolah dengan Model School Feeding dan Non School Feeding. Kesmas, Vol. 7, No. 2, 97-98. 